\title{
De ernst van het leven : een afscheid
}

Citation for published version (APA):

Verhey, F. H. M. (1991). De ernst van het leven : een afscheid. Afdeling Klinische Psychiatrie Academische Ziekenhuis Maastricht. https://doi.org/10.26481/spe.19910607fv

Document status and date:

Published: 07/06/1991

DOI:

10.26481/spe.19910607fv

Document Version:

Publisher's PDF, also known as Version of record

\section{Please check the document version of this publication:}

- A submitted manuscript is the version of the article upon submission and before peer-review. There can be important differences between the submitted version and the official published version of record.

People interested in the research are advised to contact the author for the final version of the publication, or visit the DOI to the publisher's website.

- The final author version and the galley proof are versions of the publication after peer review.

- The final published version features the final layout of the paper including the volume, issue and page numbers.

Link to publication

\footnotetext{
General rights rights.

- You may freely distribute the URL identifying the publication in the public portal. please follow below link for the End User Agreement:

www.umlib.nl/taverne-license

Take down policy

If you believe that this document breaches copyright please contact us at:

repository@maastrichtuniversity.nl

providing details and we will investigate your claim.
}

Copyright and moral rights for the publications made accessible in the public portal are retained by the authors and/or other copyright owners and it is a condition of accessing publications that users recognise and abide by the legal requirements associated with these

- Users may download and print one copy of any publication from the public portal for the purpose of private study or research.

- You may not further distribute the material or use it for any profit-making activity or commercial gain

If the publication is distributed under the terms of Article $25 \mathrm{fa}$ of the Dutch Copyright Act, indicated by the "Taverne" license above, 

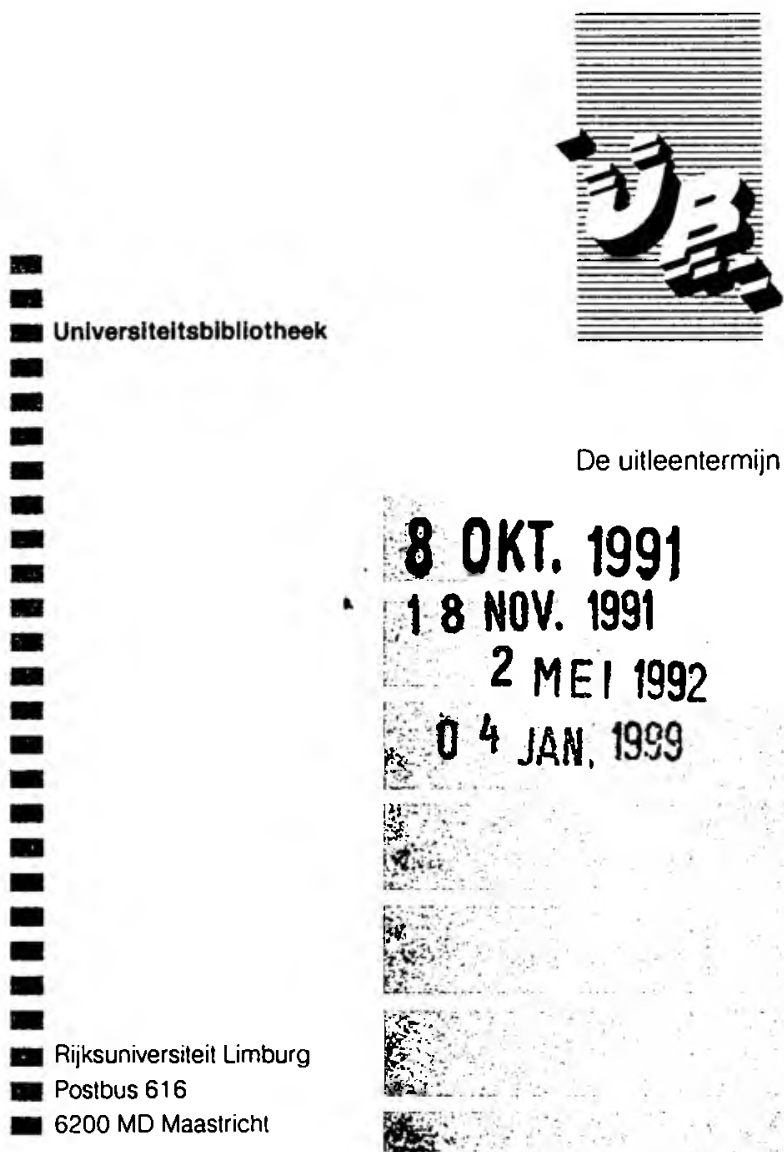

De uitleentermijn verstrijkt op:

8 OKT. 1991

- 18 NOV. 1991

2 MEI 1992

O 4 JAN 1999

is

(2)

2.

(c)

$x$

E.:

to

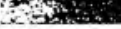

trower.

into

itasi: $:$

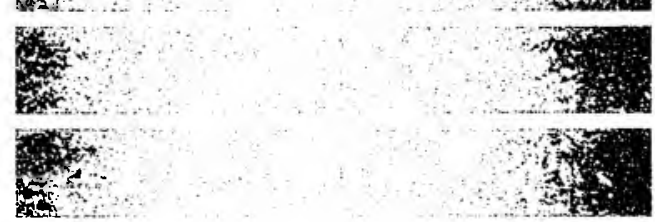

Gelieve deze publicatie tijdig te retourneren of (telefonisch) verienging van de vitleentermijn aan te vragen. 


\section{DE ERNST VAN HET LEVEN}

\section{EEN AFSCHEID}

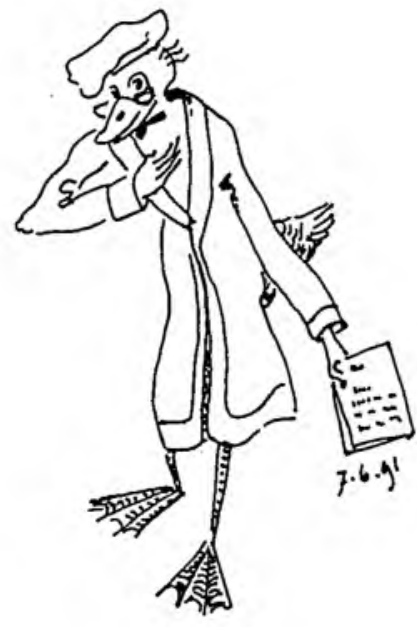


Uilgave : Afdeling Klinische Psychiatrie

Academische Ziekenhuis Maastricht

Copyright: Prof. dr. F. H. M. Verhey 


\title{
DE ERNST VAN HET LEVEN
}

\section{EEN AFSCHEID}

\author{
Afscheidscollege \\ uitgesproken bij het afsluiten \\ van het ambt van Hoogleraar \\ in de klinische psychiatrie \\ aan de Rijksuniversiteit Limburg \\ op Vrijdag 7 Juni 1991
}

door

Prof. dr. F. H. M. Verhey

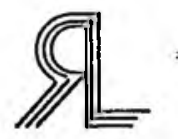

Rijksuniversiteit Limburg 


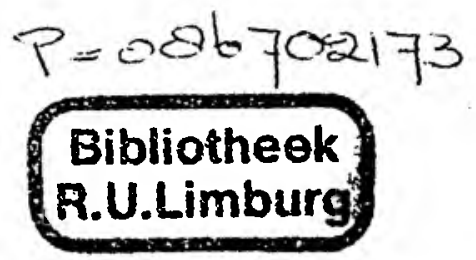


DE ERNST VAN HET LEVEN. EEN AFSCHEID.

Afscheidscollege

uitgesproken op Vrijdag 7 Juni 1991 bij hel atsluiten van het ambt van Hoogleraar in de Klinische Psychiatrie aan de Rijksuniversiteit Limburg

door Prof. dr. F.H.M. Verhey.

Dames en Heren, leden van de Universitaire Gemeenschap en voorts Gij Allen, die door Uw aanwezigheid blijk geeft van Uw belangstelling.

INLEIDING

Dit is een afscheidscollege. Een openbare les derhalve, waarbij ik verondersteld word, bij mijn afscheid, $U$ iets mee te geven. Niet zo maar iets. Neen, iets voor het leven. lets ernstigs dus.

Een afscheid. En dan? Hoe verder? Wat doe je met de jaren, die nu komen? Je weet niet hoeveel dat er zullen zijn. Hoe zal de "quality of life" zijn in die jaren? Je weet bijvoorbeeld niet wat je gezondheid je zal toelaten. Hoelang je partner, je familie, je vrienden er zullen zijn. Het antwoord op dergelijke vragen heb je natuurlijk nooit geweten, maar nu begin je ze wel te stellen.

Als mensen mij vragen wat ik nu ga doen, geef ik een ontwijkend antwoord. Ik verzin maar wat. Ik weet het zelf niet echt. Niet konkreet. Ik denk dat het zo iets is als ophouden met roken. Ophouden met iets waaraan je een beetje verslaafd bent. Het lijkt erger dan het is. Er komen formules naarboven, die ik de laatste jaren vooral in de beleidspsychiatrie geleerd heb. "Ik zal, gezien de onzekerheden die ik hierboven enigszins heb aangeduid, een flexibel beleid moeten uitstippelen. Alleen de grote lijnen. Liefst dé grote lijn".

Er zijn cursussen voor mensen die met pensioen gaan. "Het grote gat". Daar moet je niet invallen. Vooral de Fransen zijn daar niet optimistisch over: "Partir c'est mourir un peu". Dat valt nog mee. "La vieillesse c'est une ruïne" zei Charles de Gaulle en Jaques Brei, even eenvoudig als duidelijk : "Vieillir c'est crapuleux". Ik ben dus gewaarschuwd. Een legertje hulpverleners, organisaties en instituten staat klaar : bejaardentehuizen, verzorgings-en verpleegtehuizen, Gaazen vol geriaters en psychogeriaters, kruisverenigingen, wijkzusters, maatschappelijk werkers, de sociaalpsycho-geriatrische dienst, de geheugenpoli en het multidisciplinaire geriatrische consult.

Een aantal daarvan heb ik mede geinitieerd. Ik ben daarvoor meerdere malen geridderd o.a. als gerontoprovo door de SPGD en, vorig jaar nog, met het gebroken zilveren krukje door het RIAGG..

Toch moet ik proberen uit hun handen te blijven. Misschien als ik beter weet waarvan ik afscheid zal nemen, dat ik dan ook beter een antwoord weet op de vraag : hoe verder ? 


\section{AFSCHEID VAN WAT?}

Afscheid, van wie of waarvan dus ?

Van U mijn collega's, medewerkers, vrienden en familieleden ? Nee. Dat is praematuur, gelukkig ook niet waarschijnlijk en in ieder geval niet mijn bedoeling. $U$ heb ik hard nodig.

Van mijn taken in de gezondheidszorg ? Van mijn patienten ? Van vele duizenden, die ik in de eenendertig jaar van mijn Maastrichtse loopbaan mocht onderzoeken en behandelen, heb ik in het verleden al afscheid genomen, omdat de behandeling om de een of andere reden een einde vond. Vaak tot ieders tevredenheid. Psychiatrie is een medisch specialisme met, over het algemeen en ondanks wat wel eens gedacht wordt, opbeurende resultaten. Er zijn heel veel patienten waar ik met plezier aan terugdenk en net bij een gelegenheid als deze, merk je dat dit vaak wederzijds is.

Voor een beperkte groep, die tot voor kort nog in behandeling was, heb ik, in onderling overleg, onlangs een voortzetting van de behandeling elders moeten bedenken en realiseren. ledere behandeling is, als het goed is, een verhaal, met een begin en een slot. In dit geval werd het verhaal voortijdig afgebroken. Dit afscheid was vaak ontroerend en viel dus onder de ernstige zaken van het leven.

Ik had een eigen soort praktijk. Naar mijn gevoel nogal persoonlijk. Ik heb mij, en naar ik vrees deden anderen dat ook, vaak afgevraagd of dat wel wetenschappelijk genoeg was. Die vraag alleen al stelde mij echter enigszins gerust. Velen komen aan die vraag niet toe.

Het is belangrijk dat men zich zulke vragen blijft stellen. Bovendien sluit het ene het andere niet uit. Dat is naar mijn mening zelfs een van de grondregels van de psychiatrische gezondheidszorg : een twee sporen activiteit, een stereo-effect met één warm menselijk geëngageerd spoor en gelijktijdig één wetenschappelijk, vakmatig waarnemend en analyserend spoor, het spoor van je vakkennis, je deskundigheid waar je voor betaald wordt. In een ander jargon : een empathisch en een abstinerend spoor.

Afscheid van onderwijs en onderzoek? Niet helemaal. Een stukje onderzoek kan ik nog blijven doen. Voor mij is dat trouwens altijd een hobby geweest. Je kunt gerust zeggen een vrijetijdsbesteding. In mijn werktijd is dat niet of nauwelijks gelukt. Dat blijft dus zo. Een hobby voor mijn toegenomen vrije tijd.

Van de afdeling ? Ja, vooral de afdeling. Er verandert veel. Voor mij en voor de afdeling. De gelegenheid voor dit afscheid is mij door de afdeling enige dagen geleden aangeboden. Ze noemden dat "a sentimental journey". Daarin hadden zij gelijk. Dat was hartverwarmend, ontroerend en dus ook ernstig, niet alleen komiek. 
Daar zal ik hier niet over spreken. Forme日l is dat achter de rug. Een grote genegenheid blijft.

In deze academische rede zal ik mij abstraheren van de gevoelsmatige zaken. Dat geeft mij de gelegenheid om te komen tot de kern van mijn betoog.

Hier, op deze plaats en nu, op dit moment wil ik trachten afscheid to nemen van iets dat me al lang hinderde. Ik zou afscheid willen nemen van een nogal komplex geheel, samengevat als (waarschijnlijk had $U$ dat al begrepen) de tyrannieke ernst van het leven. Wellicht dat ook $U$ daar iets aan heeft.

\section{DE ERNST VAN HET LEVEN.}

Wat is dat eigenlijk ? Het antwoord op die vraag is, bij nader inzien, niet zo eenvoudig. Ik heb het idee dat het in de puberteit begonnen is, ik herinner me niet precies wanneer. In het begin van mijn gymnasiumjaren. Je moet er in ieder geval een bepaalde leeftijd voor hebben. lemand kwam daar voor het eerst mee voor de dag. Nog niet kwaad bedoeld. Dan, voor je het weet, word je er van alle kanten door omringd. Ik heb er nooit van gehouden. Het heeft te maken met de kennis van goed en kwaad. Een afscheid van het aardsparadijs. Het is uitgevonden om me in het gareel te houden. "Jongeman, je bent niet ernstig". Het werd gebruikt vooral door leraren en andere gezagsdragers. Je mocht er geen grapjes over maken.

Ofschoon ze er alle kanten mee opkonden heeft het in ieder geval te maken met plicht en "law and order", met het geweten en met biechten, met boete,straf, ziek zijn en dood gaan, met emoties en hartstochten, het "über ich", met helden en heiligen, het hiernamaals en het laatste oordeel. lets héél belangrijks. De ernst van het leven wordt pas zichtbaar als je de humor begint te ontdekken. Zoals het licht komt in de duisternis, zo tekent de humor zich af tegen de ernst van het leven.

\section{HET KOMIEKE VAN HET LEVEN}

Als men bij de eerste pogingen om iets te omschrijven of te definiëren niet slaagt, is het niet ongewoon ook eens naar het tegenovergestelde te kijken. Over de ernst van het leven wordt vooral gesproken in literatuur die gaat over het tegenovergestelde, over de humor, de grap en het lachen. Daarover bestaat zoveel literatuur, dat ik verplicht was een keuze to maken.

Ik heb me tot drie inhoudsdeskundigen, beperkt. Als psychiater heb ik op de eerste plaats twee bekende mannen uit mijn vakgebied aan het woord gelaten : Kraeplin (wie had dat gedacht?) : Zur Psychologie des Komischen (1885) en (lk zou haast zeggen, natuurlijk) Sigmund Freud met : Der Witz und seine Beziehung zum Unbewusten (1905). 
Die titel lijkt zelf al een "Witz".

In de tijd gezien, daar tussen in, in 1900, schreef de Franse philosoof Henri Bergson de verhandeling : Le Rire. Het lachen.

Kraeplin gaat, zoals ook Freud, in op de "Technik des Witzes" en ziet vooral de relatie met en de afgrenzing van de psychopathologie. Ook heel interessant, het belachelijke en het gekke, het onschuldige gekke en het echte gekke. Daar komen we dadelijk nog even op terug.

Freud benadrukt het lustelement in het lachen, de relatie met de droom en het daarin vervatte heimwee naar kinderlijke paradijzen.

Bergson ziet in het lachen vooral een sociaal alarm, een spontane tuchtiging door de groep, telkens wanneer er op een bepaalde manier met het leven geknoeid wordt. Wonderlijk hoe daar, net als bij de ernst van het leven, toch weer die zedenverbeterende tendens in zit. Ze kunnen het niet laten. Maar toch...een meer aantrekkelijk alternatief. En daar gaat het om. De Engeise auteur Chesterton, aan wie ik in mijn leven veel te danken heb, stelde dat wij een groot deel van de maatschappelijke stoutigheid veel te ernstig opnemen, als misdaden, die door de justitie volwassen behandeld en gestraft worden. Hij stelde voor om de kinderachtige misdragingen, volgens hem de meeste, ook kinderachtig te straffen. In de hoek zetten en zo. Hij stelde voor de schandpaal weer in te voeren. Onmiddellijk verschijnt dan voor mij het beeld van Maarten van Rossum die in de schandpaal gekluisterd, gelukzalig glimlacht, terwijl hij een trekje neemt uit de lange goudse pijp die een vriendelijk jongetje hem voorhoudt. Van Rossum's troost. Hij zal het nooit meer doen.

Lachen in plaats van de ernst van het leven. Vooral daardoor bood Bergson mij de meeste aanknopingspunten voor dit betoog.

\section{BERGSON OVER HET KOMISCHE. EEN STUKJE THEORIE.}

Wanneer is iets om te lachen ?

Ik kan het best beginnen met een klassiek voorbeeld: een verstrooide professor loopt te filosoferen over de wetten van het heelal en de sterren. Hij stapt op een bananenschil. Hij glijdt uit, maakt enkele snelle, clowneske gebaren met zijn armen en de rest van zijn lichaam en valt op de grond. Zijn verstrooidheid heeft hem onoplettend gemaakt, waardoor hij onaangepast, werktuiglijk gedrag vertoont. Wie het ziet "schiet in een lach" wat enerzijds een signaal is naar de omgeving, anderzijds een bevrijding van eigen schrikgevoelens.

Als het leven iets automatisch, stars of mechanisch krijgt is dat komisch. Wat onaangepast is, niet flexibel, niet soepel, is om te lachen. Dit is de meest wezenlijke voorwaarde : Een werktuiglijke starheid en onbuigzaamheid, de starheid van een machine daar, waar men de opmerkzame soepelheid en de lenigheid van de mens verwacht. Een vorm van onvrijheid die men had kunnen voorkomen. 
Vaak zit dit werktuiglijke in een persoon. Hij is verstrooid, romantisch, jaagt een hersenschim na, is fanatiek, heeft een bepaalde karaktertrek, een gebrek of ondeugd. Dat kan zich uiten in een grimas, een werktuiglijke motoriek, als een ledepop, een marionet, een clown.

Soms ook zetelt het komische in een groep, een systeem, een instituut met eigen vooroordelen on subculturele waanvorming. Kadaverdiscipline of bureaukratie kunnen bijvoorbeeld tot zeer lachwekkende toestanden leiden. Charley Chaplin heeft, als niemand anders, begrepen wat de komische werking van een werktuiglijke motoriek is. Maar ook een verstarring in de groep, de gemeenschap, het systeem., zoals in "modern times" of "de dictator".

De persoon, de instelling is zich hier zelf niet van bewust. Wil het niet. Het komieke gebrek is als een parasiet, is min of meer oppervlakkig, een luis in de pels. De persoon "HEEFT" een bepaald gebrek, "IS" het niet.

Ofschoon hij het aan eenieder toont, is hij zich van dit gebrek niet bewust. Het draait in een blijspel om het lachwekkende gebrek niet om deze of gene die daar de drager van is. Komedies worden daarom ook meestal genoemd naar het ingebouwde mechanisme, gebrek of ondeugd, bijvoorbeeld : de vrek of de ingebeelde zieke.

Als een persoon bewust en volledig opgaat in een ondeugd, zich vrijwillig daaraan overgeeft, dan is er geen sprake van een komedie of een blijspel. Dan is er sprake van een treurspel, een drama. Dan kan men niet meer om hem lachen en is hij slechts een humorloze held.

De held in een drama gaat helemaal op in zijn gebrek, identificeert zich daar volledig mee. Vandaar dat drama's genoemd zijn naar een persoon : Othello, King Lear of MacBeth.

Het komische is die vervorming van het leven die ons doet lachen. Humor heeft hij, die een scherp waarnemer is van die komieke variant, ons dat ook onmiddellijk kan laten zien of zelf konstructies kan maken waarin deze situatie als het ware "in vitro" voorkomt : de grap.

Lachen tenslotte is een uiterst menselijke, ontspannende, lust en genot verschaffende, soms ontwapenende reactie vanuit de gemeenschap, een sociaal alarm : er is iets geks aan de hand, dit kan niet.

Er zijn drie beperkende voorwaarden :

1. Alleen mensen kunnen lachen. "De mens is een dier dat kan lachen". De humor hoort bij het hoogste ontwikkelingsniveau in de evolutie. Het hoort bij het hoge intellectuele niveau van vrijheid, dat typisch is voor de mens. Op menselijk niveau ontwikkelt de humor zich tegenover de ernst, "Die Tierische Ernst". Alleen de mens kan het leven weergeven als een mengsel van ernst én humor, zoals een schilder een compositie maakt van licht en duisternis. Denk maar eens aan het "claire-obscure" waar de Rembrandtkenners het altijd over hebben. 
2. Er mag geen sprake zijn van verdriet, medelijden, boosheid of enige andere drift of emotie. Dat zijn immers betrekkelijk ouderwetse verschijnselen van de menselijke geest samenhangend met meer primitieve, oudere delen van de hersenschors. Bij iedere emotie verdwijnt onmiddellijk al het komische; dan vergaat $U$ het lachen.

3. Men mag niet buitengesloten zijn. Men moet erbij betrokken zijn, je moet bij dezelfde club horen. lets is alleen komisch binnen een bepaalde groep. Lachen is steeds een sociaal alarm.

Men kan uit deze punten de konklusie trekken dat ernst en humor steeds betrekking hebben op menselijke situaties, waarbij de keuze, of vaker nog het mengsel van beide bepaald wordt zowel door de aard van de lachwekkende bron als door de instelling van de groep, waarin deze ontspringt.

\section{JAAR PSYCHIATRIE. BLIJSPEL OF DRAMA}

De wetenschappelijke verhandelingen over het komische, zoals hierboven genoemd, zijn zeer aangenaam om te lezen vooral omdat er vaak zeer goede grappen in staan. Het zijn een soort bonbondozen, waaruit ik $U$, gezien de aard en de omvang van dit verhaal, helaas slechts enkele heerlijkheden kan presenteren.

Ik ben blij, ondanks de titel van mijn voordracht, dat ik vandaag niet gekozen heb om de ernst van het leven uitvoerig te beschrijven. Zoals $U$ inmiddels begrepen heeft wil ik daarvan juist afstand nemen om het tegendeel, het komische op te zoeken. Ik zou voor de treurige plicht gestaan hebben om ruim dertig jaar Maastrichtse psychiatrie van de ernstige kant te bekijken, te beschrijven als een aaneenrijging van treurspelen. Ik zou ook verplicht geweest zijn - ik heb $U$ dat net uitgelegd - om de dramatis personae bij de naam te noemen, de helden die hun naam aan de elkaar opvolgende treurspelen gegeven hebben. Na enig overleg met mezelf heb ik daarvan afgezien. Ik beperk me tot mezelf.

Als ik mijn eigen geschiedenis van ruim dertig jaar psychiatrie als treurspel zou moeten beschrijven, dan zou ik dat drama "Franciscus de eerste" moeten noemen. Ik, dat begrijpt $U$, zie het liever als een blijspel bijvoorbeeld getiteld : "het lelijke eendje in de witte jas", met als één van de acteurs : Frans d'n ierste. Dat klinkt mij niet als een held in de oren, maar meer als een hooglustigheid.

Als ik zou gaan zitten - helden doen dat overigens nooit - om mijn herinneringen op een rijtje te zetten en ik kan ze, zoals nu, zonder emoties overzien, dan lijken de blijspelen het te winnen.

Denkt $U$ bijvoorbeeld aan : "Hoogbouw komt voor de val". Een kassucces in theater Vijverdal. 
"Het Heilig Hart on het Lelijk Eendje" met gelukkig slechts twee uitvoeringen in Annadal. Blijspelen over menselijke gebreken zoals ijdelheid en hebzucht.

En dan natuurlijk de nota's: Allemaal met een of ander gebrek als komische noot, meestal geldgebrek : de rode-draad-nota, de reorganisatienota, de structuurnota en de fusienota, het primair proces en de intentienota. Machinaties, meestal met dubbele bodem, vol komische herhalingen, omkering van de waarheid en niet in elkaar grijpende knarsetandende raderwerken. Ik kan er nu om lachen. Of liever gezegd, glimlachen, want "Men lacht in de keuken en glimlacht in de salon".

Het werktuiglijke, het grappige zit nogal eens in de herhaling. Dat is vooral toegenomen sinds de invoering van de kopieermachine. Dezelfde dingen komen telkens terug. Zelden iets nieuws in al die nota's.

Of er treedt zelfs een, niet bij het leven passende, omkering op. Wat verketterd werd wordt weer geweldig populair en dan weer omgekeerd. Een slingerwerking. Soms was er ook sprake van een inhoudelijke omkering, bijvoorbeeld : De patiënt is mondig. Hij en niet de dokter is verantwoordelijk voor zijn problemen en het succes van de behandeling. "Wij zijn heel goede dokters maar de patiënten werken niet mee". De omgekeerde wereld.

Wat ook mechanisch en dus komiek is dat zijn de niet met elkaar accorderende maar wel interfererende systemen, een machine waarvan de tandwielen niet goed in elkaar grijpen. Hevig geknars. Vijverdal, RIAGG, de vakgroepen Sociale of Klinische Psychiatrie en het Academisch Ziekenhuis, een krakkemikkig raderwerk, een krakende versnellingsbak, die meer remt dan versnelt. In ieder van die subculturen treedt een eigen waanvorming op. De vertegenwoordigers van deze instellingen krijgen een geprogrammeerde, voorspelbare taal. Tijdens, overigens goedbedoelde, gemeenschappelijke vergaderingen leidt dat mechanisme tot hevig geknars. Voor de niet geemotioneerde toeschouwer een blijspel met vele delen.

\section{DEMODE}

Ook kleding en de daarbij behorende mode is om dezelfde rede in principe komisch, ofschoon we dat pas opmerken als we ons gaan "verkleden" bijvoorbeeld met carnaval. Aan onze dagelijkse kleding zijn wij zo newend, dat het lachwekkende ons zelden opvalt. Dat treedt pas op als het 'dingstuk "uit de mode is", dan loop je er bespottellijk bij. Theo Thijssen s semt een van zijn boeken naar het frustrerende nette pak van zijn hoofdpersoon : "Het taaje ongerief.

De Nederlandse psychiatrie is zeer modegevoelig. Ik geef, met enige verlegenheid, toe dat ik geprobeerd heb de mode van trendsetter RIAGG enigszins bij te houden. 
Ook al uit sympathie voor dit instituut, waar ik, in het begin van mijn professionele carrière, jarenlang op de loonlijst heb gestaan. ik had wel begrepen dat mijn driedelig grijs met een krijtstreepje daar in het begin van de jaren zeventig mij tot een Neanderthaler bestempelde. Mijn vrouw kocht dus een "kol-trui" en met een echt Riagg-gevoel ging ik naar de eerstkomende nieuwjaarsborrel. Gelach, natuurlijk wel met veel begrip. Allemaal chique in het pak, met een brede das, speciaal kraagje en een niet geperste bandplooibroek. Ik was de enige kol-trui.

Niet alleen aan de buitenkant bleek ons vak modegevoelig. Ik heb sinds het moment dat ik belangstelling voor psychiatrie kreeg heel wat modehuizen zien passeren : biologische, psychodynamische of sociale trends. Een extra komische noot werd steeds gevormd door de sectarische ernst waarmee deze dogma's werden gepredikt. Ik heb dit altijd voor typisch Hollands gehouden. "Un Hollandais c'est un théologien, deux Hollandais c'est une religion, trois Hollandais c'est un schisme". Echte "zwarte kousen kerken". Een soort mode, niet toevallig naar een kledingstuk genoemd. Ofschoon eenieder het ene ware geloof verkondigde, de integrale psychiatrie, bleek in de praktijk al gauw of men biologische danwel psycho-sociale kousen droeg. Vooral als er weer eens een bezuinigingsblijspel opgevoerd moest worden, dan bleek al gauw hoe de keuzes gemaakt werden, hoe de eigenlijke trend voor het nieuwe seizoen was, welke kleur kousen de nieuwlichters droegen.

Ik heb zelf ook op een andere manier aan de mode gedaan, of liever koppig blijven vasthouden aan een soort anti-mode. Ik heb, telkens als ik bezig was met rechtstreekse patientenzorg, een witte doktersjas gedragen.

Voor anderen zal dat wel komisch geweest zijn, een blijspel "het lelijk eendje met de witte jas". Maar dat is, zoals ik $U$ uitgelegd heb, juist een van de eigenschappen van het komieke : het lachwekkende subject is zich daar niet van bewust. Voor mij is dat een ernstige zaak. Anderen lachen er om. Ik doe dat om aan te geven dat ik de dokter van het team ben en dat het doktersvak geen proper, elegant vak is.

Hygiënisch bedoelde werkkleding, waaraan je de dokter kunt herkennen. Patienten hebben er recht op te weten in welke rol Dirk Jan of Sitske hen lichamelijk onderzoekt. Dat wil zeggen, áls hij of zij nog een lichamelijk onderzoek doet.

Wie dualistisch denkt en dus lichaam en ziel van de mens ziet als twee verschillende zaken, die op een bepaalde manier met elkaar bezig zijn, kan op de gedachte komen, dat het lichaam een lastig stoffelijk omhulsel is, waarin de ziel bekneld zit. De ziel wordt geplaagd door de behoeften van dat domme koppige lichaam. Broeder ezel noemde Franciscus dat. In de achter ons liggende twintig jaar is het lastige lichaam in de psychiatrie niet geliefd geweest. Sommigen, wat eenvoudigen van geest, hielden zich daarmee bezig. Dokters dus. In de psychiatrie van de afgelopen decenniën werd het lichaam als het ware ontkend. 
Dat was waar dokters hun macht aan ontleenden. Dat ging uiteindelijk zover dat lichamelijk onderzoek in de psychiatrie taboe was. Daarmee bracht men de mondige kliënt weer in de passieve patiëntenrol. Het hele medische model was een zeer verwerpelijk en autoritair concept. De witte jas was daarvan het symbool. Deze klucht heeft $z$ 'n hoogtepunt gelukkig weer gehad. Dat werkte niet. De eersten die dat door hadden waren de patiënten zelf. Zij wilden desnoods ziek zijn, maar niet gek. Deze mode heeft het stigma van de psychiatrische patiënt sterk in de hand gewerkt.

\section{DE VERMOMMING VAN HET LEVEN ZELF.}

Zijdelings heeft ook deze plechtigheid natuurlijk te maken met een verkleedpartij, een vermomming. $U$ moet eens kijken hoe ik er hier bij sta. Hoe we hier binnen kwamen. Als men zich distantieert van de ernstige inhoud - en daar nodig ik $U$ voortdurend toe uit - zijn wij, de deelnemers aan deze ceremonie, als marionetten. Volgens ijzeren regels van een protocol en als trekpoppen in de handen van de pedel bewegen wij ons, stijlvol en indrukwekkend. In die zin is iedere plechtigheid komisch. Het leven wordt hier gestuurd door een mechanisme, een vast programma. Dat is lachwekkend. Toch doe ik hier graag aan mee.

Ik ben ervan overtuigd dat mijn kinderen en mijn broers, als ze mij hier zo zien staan, een glimlach niet kunnen onderdrukken, in het Maastrichts "griemele", zo iets als "besmuikt lachen". Het moet een blijspel zijn en blijven. Aanvankelijk had de RL zich voorgenomen om van deze ceremonies af te zien. Gelukkig hebben ze het gauw begrepen.

Plechtige regels, meestal voortkomend uit ijdelheid, die belangrijker worden voorgesteld dan de regels van de natuur zijn rechtuit belachelijk. Sommige beroepen nodigen daartoe uit. De geneeskunst niet op de laatste plaats. Vele spotprenten van Daumier en ontelbare uitspraken in blijspelen onderstrepen dit.

Molière, de spotvogel bij uitstek, laat meneer de Pourceaugnac tegen de zenuwarts zeggen : "Het beloog dat gij hebt gehouden, is zo geleerd en zo schoon, dat de zieke onmogelijk iets anders hebben kan dan melancholische hypochondrie; en wanneer hij het niet mocht hebben, dan zal hij het moeten krijgen, terwille van de schoonheid van alles wat gij gezegd heb en van de juistheid van het oordeel dat gij hebt uitgesproken".

Een ander voorbeeld dat ik niet kan nalaten $U$ te vertellen; ook bij Molière: Sganarelle aan Géronte, wanneer deze laatste opmerkt dat het hart aan de linkerkant en de lever aan de rechterkant zit : "Ja, dat was vroeger zo, maar wij oefenen thans de geneeskunst uit volgens een geheel nieuwe methode ". 


\section{DE KOMISCHE PERSOON, DE GRENS MET DE PSYCHOPATHOLOGIE.}

Het komische zit in het werktuiglijke. In deze tijd, gewend aan computers, zou men zeggen : in het programma. Nu leerden wij in de psychologie dat de persoonlijkheid, het karakter bestond uit "de habituele wijze van ageren en reageren". Zo is hij dus geprogrammeerd. Daarom kun je van hem niet anders verwachten.

Vandaar dat ieder karakter, ieder type een kern van humor in zich draagt. Als de persoon zich daarvan echter bewust is en hij reageert opzettellijk zo dan is dat niet komisch. Als dat onbewust en onvrijwillig gebeurt dan kan het belachelijk zijn. Tenminste, en dat is de wezenlijke grens met de pathologie, als dat geen emoties oproept. Wat op het toneel, of zelfs bij de buurman is om je dood te lachen, kan in eigen huis of gezin leiden tot irritatie, woede of een andere emotie, die alles behalve komisch is. Uitingen van een bepaalde persoonlijkheidsstoornis, die nu, op dit moment niet komisch zijn en hevige emoties oproepen, kunnen een tijd later, als de zaak niet meer actueel is en zijn emotionele lading heeft verloren, tot hevige lachbuien leiden wanneer men dat in een groep navertelt; "Ik kan er nu om lachen". Gestoord gedrag kan tegelijkertijd voor de een een bron zijn van grote zorg en verdriet en voor de ander, die niet bij de groep hoort, die het niets doet, een aanleiding zijn om zich uitbundig te amuseren.

$U$ ziet : de psychopathologie en het komische liggen soms kort bij elkaar. Of iets ziek is of alleen maar komisch is, ligt niet alleen aan de aard van de aandoening, maar ook aan de instelling van de toeschouwer en de groep waarin het speelt. Doet het hem emotioneel niets of hoort hij niet tot de groep dan is het om te lachen. Is het "echt gek", is er sprake van psychopathologie dan is dat een ernstige aangelegenheid.

\section{AFSCHEID VAN DE ERNST VAN HET LEVEN}

Welnu, ik neem afscheid van de psychopathologie en dus ook in dit opzicht van de ernst van het leven.

ik ben mij ervan bewust dat ik het mij daarmee overigens niet gemakkelijker maak. Alleen normaliteit is oneindig variabel en gezondheid is eindeloos genuanceerd. Gezond zijn betekent vrij zijn, vrij om alles te kunnen, om alles te zijn. Het aantal manieren van gezond zijn is eindeloos. Het aantal manieren van ziek zijn is beperkt. Gezondheid kan niet in eenvoudige schema's, zoals de DSM III-R of in de 140 vakjes van de Present State Examination gevat worden. Daarvoor zijn echte kunstenaars, schrijvers, dichters,schilders en beeldhouwers nodig. En dan nog.

Chesterton, die ik al eens aangehaald heb, zegt hierover : het meest poëtische gedicht over verliefd zijn haalt het in de verste verte niet bij ... gewoon verliefd zijn. 


\section{THE PHILOSOPHICAL YEARS}

Simenon heeft op hoge leeftijd, veel ouder dan ik nu op mijn 65ste, een boek geschreven met de titel : "Toen ik oud was." Uit die titel blijkt al, dat hij afstand nam van zijn -oude- leeftijd. Toen ik oud WAS. Jong en oud vloeien in elkaar over. $\mathrm{Er}$ is geen echt verschil meer. Behalve dat hij nu alles kan overzien.

Men beweert dat zenuwartsen na hun zestigste "in their philosophical years" terecht komen. Zoiets moet Simenon bedoeld hebben. Een abstractie. Het mag $U$ een beetje baldadig voorkomen. Een soort euphorie, die je ook wel bekruipt als je vanaf een bergtop een groots en duizelingwekkend uitzicht overziet. "Die Erde enhoben". Minder kwetsbaar.

$\mathrm{lk}$ neem afscheid omdat ik de $\mathrm{zg}$. pensioengerechtigde leeftijd bereikt heb. die mij meer een pensioenplichtige leeftijd lijkt.

Ik heb onlangs gelezen dat 65 jaar een compromis is in de onderhandelingen tussen Bismarck en Krupp. Bismarck wilde een pensioen voor de werknemers en Krupp vond dit niet nodig. Tenslotte werd het compromis van 65 jaar bereikt omdat Krupp wist dat zijn arbeiders die leeftijd toch niet haalden.

Voor mij is het goed zo. Je moet de tijd hebben om al die veranderingen, vooral het afscheid van de tiranieke ernst van het leven en het op creatieve wijze omgaan met humor en gezondheid in te oefenen.

Rest mij om $U$ allen te bedanken voor de vele goede dingen, die $U$ mij gegeven heeft en voor de lessen, die $U$ mij heeft geleerd. Ik verheug mij op de komende jaren. Met $U$ en als het even kan, zonder teveel ernst van het leven. 
